\title{
IrO $_{\mathrm{x}}$ and Pt-Ir Electrochemical Sensors: Prospective Enzyme-less pH and Glucose Sensors for Continuous Monitoring in Cell Culture
}

\author{
Yueh-Yuan Fang ${ }^{1}$, Yi-Cheng Hsieh ${ }^{2}$, Chii-Wann Lin ${ }^{1,3,4}$ \\ ${ }^{1}$ Institute of Biomedical Engineering, National Taiwan University, No. 1, Sec. 4, Roosevelt Road, \\ Taipei, Taiwan \\ ${ }^{2}$ Corning research Center Taiwan (CRC-T), Room 826, Bldg. 53, No. 195, Sec. 4, Chung-Hsin Road, \\ Chutung, Hsinchu County, Taiwan \\ ${ }^{3}$ Institute of Electrical Engineering, National Taiwan University, No. 1, Sec. 4, Roosevelt Road, Taipei, \\ Taiwan \\ ${ }^{4}$ Center for Emerging Material and Advanced Devices, National Taiwan University, No. 1, Sec. 4, \\ Roosevelt Road, Taipei, Taiwan \\ Chii-Wann Lin: CWLINX@ntu.edu.tw
}

\begin{abstract}
This study reports the development of two enzyme-less biosensors by using $\mathrm{IrO}_{\mathrm{x}}$ for $\mathrm{pH}$ and $\mathrm{Pt}-\mathrm{Ir}$ for glucose sensors. Nanostructures of electrodeposited $\mathrm{IrO}_{\mathrm{x}}$ and $\mathrm{Pt}-\mathrm{Ir}$ were examined by SEM and XPS on the electrode surfaces. We used chronopotentiometry (CP) for $\mathrm{pH}$ and linear sweep voltammetry (LSV) for glucose measurement at $37^{\circ} \mathrm{C}$ in $1 \mathrm{X}$ PBS $(0.15 \mathrm{M} \mathrm{NaCl})$. In the physiological range of $\mathrm{pH} \mathrm{4-10} \mathrm{and} \mathrm{glucose} \mathrm{concentration} 1 \mathrm{mM}-12 \mathrm{mM}$, these two biosensors exhibited good linearity of $-68.5 \mathrm{mV} / \mathrm{pH}\left(\mathrm{R}^{2}: 0.99\right)$ and, $0.97 \mathrm{~mA} / \mathrm{mM}-\mathrm{dm}^{2}\left(R^{2}: 0.988\right)$, respectively. Because the linear ranges are suitable for cell culture, the presented electrochemical sensors are prospective for applying to continuous cell culture monitoring.
\end{abstract}

Key words: electrochemical sensor, $\mathrm{pH}$, glucose, and continuous cell culture monitoring

\section{Introduction}

Cell culture is a complex process, especially for stem cell culture. Stem cell researches have been developed since 1960s $[1,2]$ and have thrived in recent decades. These cells are charming and different from other cells because they have a remarkable potential either to renew themselves or to differentiate into specific types of cells. Due to their flexible characteristic, stem cells become a source for drug screening and a candidate for cell-based therapies. Lots of efforts have been made to construct an additionally physical constrain in the culture environment to differentiate stem cells into a specific cell-lineage or to maintain stem cells undifferentiated [3-6]. Not only the shape or size of stem cell colonies can influence the development of stem cells, but the ingredients of the culture medium also plays a vital role in developing stem cells. Nevertheless, few studies have focused on real-time monitoring the whole processes of cell culture [7], especially for stem cells culture.
The sensors used in cells culture monitoring must have ability to reflect the real state of stem cells. Several key sensing parameters such as $\mathrm{pH}$, lactate production, glucose concentration, and oxygen consumption which are capable of indicating the function of cell metabolism are the candidate targets in the monitoring system. Mohr et al. and Weigl et al. provided an optical sensor which can detect $\mathrm{pH}$, oxygen, and carbon dioxide $[8,9]$. The sensing principle is based on the absorbance or luminescence of the fluorescence dye. Nevertheless, the drawbacks of optical sensors are the interference of turbidity/ bubbles and the sensing range limited by the dye. An alternative choice is nuclear magnetic resonance spectroscopy (NMR). It is a powerful tool for investigating physical, chemical and biological properties of samples. Several studies employed 19F NMR to determine the oxygen distribution within a cell culture system $[10,11]$. However, the cost of NMR spectroscopy is extremely expensive and it is not suitable for continuous cell culture monitoring. The third one is an electrochemical sensor which is the 
most common use in $\mathrm{pH}$, oxygen and glucose bioreactors. It can provide a quick and reliable result and the fabrication cost is low.

In this paper we proposed two sensors, a $\mathrm{pH}$ sensor and a glucose sensor, which are prospective for continuous cell culture monitoring. The $\mathrm{pH}$ sensor is made by $\mathrm{IrO}_{x}$ which is proved to be sensitive to $\mathrm{pH}$ value and have long-term stability over a month [12]. The evaluation of the $\mathrm{IrO}_{\mathrm{x}}$ electrodes, which were electroplated by different parameters, would be provided. The glucose sensor is based on nanostructured Pt-Ir. The sensing principle of the $\mathrm{pH}$ sensor and the glucose sensor is by electrochemistry.

\section{Experimental}

Reagents and Preparation of Electrolytes

Iridium tetrachloride $\left(\mathrm{IrCl}_{4}\right)$, hydrogen peroxide $\left(\mathrm{H}_{2} \mathrm{O}_{2}, 30 \%\right)$, Oxalic acid dehydrate $\left(\mathrm{C}_{2} \mathrm{H}_{2} \mathrm{O}_{4} \cdot 2 \mathrm{H}_{2} \mathrm{O}\right)$, Anhydrous potassium carbonate $\left(\mathrm{K}_{2} \mathrm{CO}_{3}\right)$, Glucose, $\mathrm{H}_{2} \mathrm{PtCl}_{6} \cdot 6 \mathrm{H}_{2} \mathrm{O}$, hydrogen chloride $(\mathrm{HCl}, 18 \mathrm{wt} \%)$, and phosphate-buffered saline (PBS) were purchased from Aldrich. Iridium (III) chloride $\left(\mathrm{IrCl}_{3}\right)$ was obtained from Alfa Aesar. Reagentgrade materials and deionized water (resistivity $\geq 18 \mathrm{M} \Omega$.) were used to prepare the electrolytes.

To prepare the electrolyte for $\operatorname{IrO}_{x}$ electroplating, $75 \mathrm{mg}$ of $\mathrm{IrCl}_{4}$ was dissolved in $50 \mathrm{ml}$ of D.I. water and the solution was stirred for 15 minutes. Then, $0.5 \mathrm{ml}$ of $30 \%$ of $\mathrm{H}_{2} \mathrm{O}_{2}$ was added into the solution and the solution was stirred for another 10 minutes. Next, 250 $\mathrm{mg}$ of $\mathrm{C}_{2} \mathrm{H}_{2} \mathrm{O}_{4} \cdot 2 \mathrm{H}_{2} \mathrm{O}$ was added and the solution was stirred for another 10 minutes. Finally, a small amount of anhydrous potassium carbonate was used to adjust the $\mathrm{pH}$ value of the solution to $\mathrm{pH} 10.5$ and the solution was stored at room temperature for 2 days to allow for stabilization. After two days, the solution was stored at $4^{\circ} \mathrm{C}$ and it is ready for later $\mathrm{IrO}_{x}$ electroplating [13].

To prepare the electrolyte for $\mathrm{Pt}-\mathrm{Ir}$ electroplating, $1 \mathrm{~g}$ of $\mathrm{H}_{2} \mathrm{PtCl}_{6} \cdot 6 \mathrm{H}_{2} \mathrm{O}$ and $1 \mathrm{~g}$ of $\mathrm{IrCl}_{3}$ were dissolved in $1 \mathrm{~L}$ and $100 \mathrm{ml}$ of $0.01 \mathrm{M}$ $\mathrm{HCl}$ solution, respectively. Then, the solution were contained and stored at room temperature for 2 days to allow for stabilization before use.

\section{Eletroplating of IrOx and Pt-Ir}

A glass wafer was covered with a $10 \mathrm{~nm}$ Ti/ $200 \mathrm{~nm}$ Pt layer that was deposited by ebeam evaporation. It was diced into small pieces $\left(2 \times 1 \mathrm{~cm}^{2}\right)$ for use as working and the counter electrodes. The reference electrode was an $\mathrm{Ag} / \mathrm{AgCl}(3 \mathrm{M} \mathrm{KCl})$ electrode. $\mathrm{IrO}_{x}$ and
Pt-Ir electroplating were performed in galvanostic mode at $30{ }^{\circ} \mathrm{C}$ without stirring (active surface area: $1 \times 1 \mathrm{~cm}^{2}$ ) and the total volume of the electrolyte mixture was fixed at 4 $\mathrm{ml}$.

For $\mathrm{IrO}_{\mathrm{x}}$ electroplating, three electrodes were separately fabricated by using different current densities, $0.25,0.3$ and $0.4 \mathrm{~mA} / \mathrm{cm}^{2}$ for 15 minutes. After electroplating of $\mathrm{IrO}_{\mathrm{x}}$, three electrodes were placed in a $\mathrm{pH} 7$ universal buffer for two days [13]. For Pt-lr electroplating, $0.5 \mathrm{ml}$ of $\mathrm{H}_{2} \mathrm{PtCl}_{6} \cdot 6 \mathrm{H}_{2} \mathrm{O}$ electrolyte and $3.5 \mathrm{ml}$ of $\mathrm{IrCl}_{3}$ electrolytes were first mixed together. Then, the Pt-Ir layer were electroplating by using current density of $-20 \mathrm{~mA} / \mathrm{cm}^{2}$ for $7000 \mathrm{~s}$.

\section{Results and Discussion \\ Characterization of the $\mathrm{IrO}_{x} \mathrm{pH}$ sensor}

To characterize the $\mathrm{IrO}_{\mathrm{x}}$ electrodes which were electroplated by different current densities, $0.25,0.3$ and $0.4 \mathrm{~mA} / \mathrm{cm}^{2}$, respectively, a 3-cell system was used to obtain calibration curves in the range of $\mathrm{pH} 4-10$. In Fig. 1, cross, square and triangle represent the chips which were electrodeposited by the current density of 0.25 , 0.3 and $0.4 \mathrm{~mA} / \mathrm{cm}^{2}$, respectively. The result shows that the chip electroplated by current density of $0.3 \mathrm{~mA} / \mathrm{cm}^{2}$ has the best linearity among the three and its sensitivity is $-68 \mathrm{mV} / \mathrm{pH}$ unit within $\mathrm{pH} 4-\mathrm{pH} 10$. The average standard deviation of this electrode is about $14 \mathrm{mV}$. Therefore, this electrode was used for further chrono-potentiometry measurement.

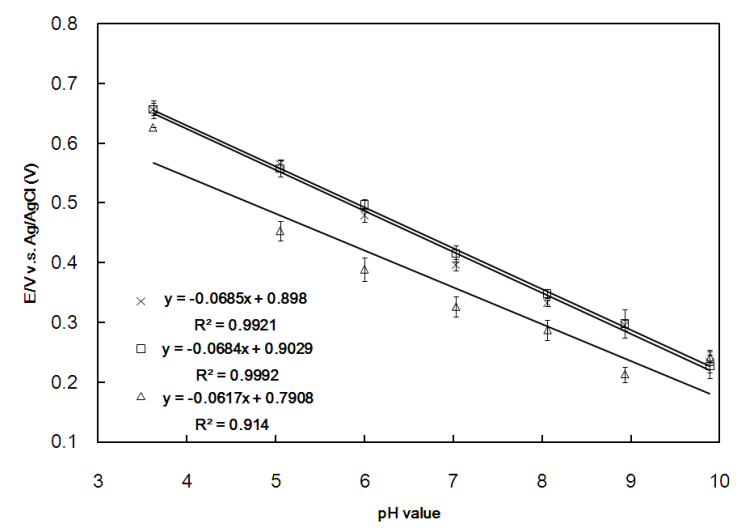

Fig. 1. The calibration curve of IrOx $\mathrm{pH}$ sensor. Cross, square and triangle represent the chips which were electrodeposited IrOx by the current density of $0.25,0.3$ and $0.4 \mathrm{~mA} / \mathrm{cm} 2$, respectively. The square line shows the best performance of the $\mathrm{pH}$ sensor and the sensitivity is $-68.5 \mathrm{mV} / \mathrm{pH}$.

To characterize the $\mathrm{IrO}_{x} \mathrm{pH}$ sensor in the solution with periodical change of $\mathrm{pH}$ value, three solutions of $\mathrm{pH}$ value $5.85,6.97$, and 7.43 were employed. Each cycle started from the solution of $\mathrm{pH} 5.85$, to $\mathrm{pH} 6.97$, last to $\mathrm{pH} 7.43$. The next cycle started when the $\mathrm{pH}$ value was 
back to 5.85 (Fig. 2). The open circuit potential (OCP) dropped with solution became more alkaline and increased when the next test cycle started.

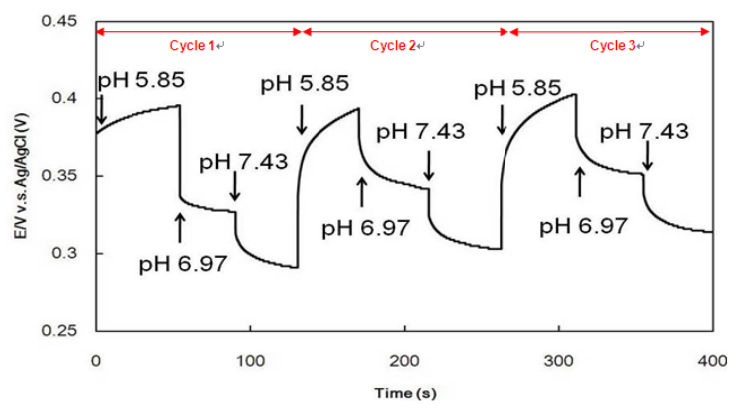

Fig. 2. The chronopotentiometry of the $\mathrm{IrO}_{x}$ electrode of sensing dynamic changes from $\mathrm{pH} 5.85$ to $\mathrm{pH} 6.97$ and last to $\mathrm{pH} 7.43$

Based on Nernst equation, one $\mathrm{pH}$ unit change would cause a difference of $59 \mathrm{mV}$ in OCP. However, the $\operatorname{IrO}_{\mathrm{x}}$ acquired by electroplating is the hydrous form and the oxide formation is more complex and the chemical formation varies depending on the deposition condition. Theoretically, the sensitivity of OCP is about $90 \mathrm{mV} / \mathrm{pH}$ unit (eq. (1)). In reality the sensitivity ranges from $59 \mathrm{mV} / \mathrm{pH}$ to $90 \mathrm{mV} / \mathrm{pH}$ [14]. In our experiment, the sensitivity was 68.5 $\mathrm{mV} / \mathrm{pH}$, which was within the range and in accordance with other previous studies.

$$
\begin{aligned}
& 2\left[\mathrm{IrO}_{2}(\mathrm{OH})_{2} \cdot 2 \mathrm{H}_{2} \mathrm{O}\right]^{2-}+3 \mathrm{H}^{+}+2 e^{-} \\
& \rightarrow\left[\mathrm{Ir}_{2} \mathrm{O}_{3}(\mathrm{OH}) \cdot 3 \mathrm{H}_{2} \mathrm{O}\right]^{3-}+3 \mathrm{H}_{2} \mathrm{O}
\end{aligned}
$$

\section{Characterization of the Pt-Ir glucose sensor}

Fig. 3(a) and 3(b) show the XPS profile of the Pt-Ir electrode and its surface morphology, respectively. The atomic ratio of the $\mathrm{Pt}-\mathrm{Ir}$ electrode is $\mathrm{Pt}(81.3 \%)-\mathrm{Ir}(18.7 \%)$. The surface structure of the Pt-Ir electrode comprises two forms of grains. One is rounded and the other is leaf-like structure.

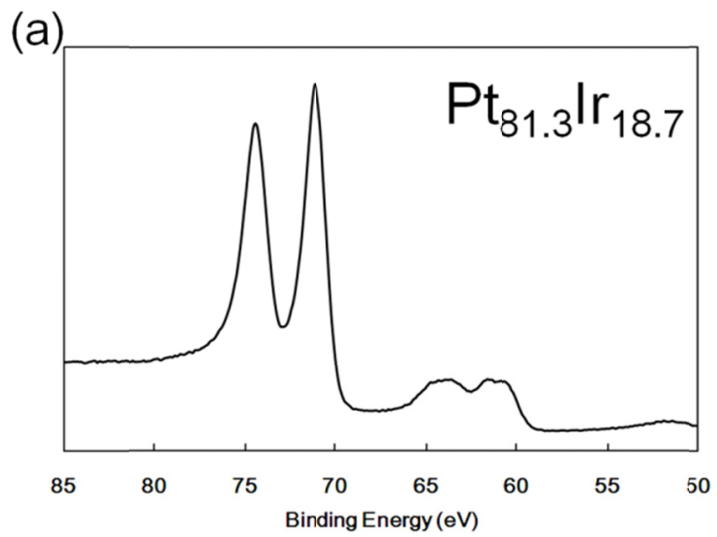

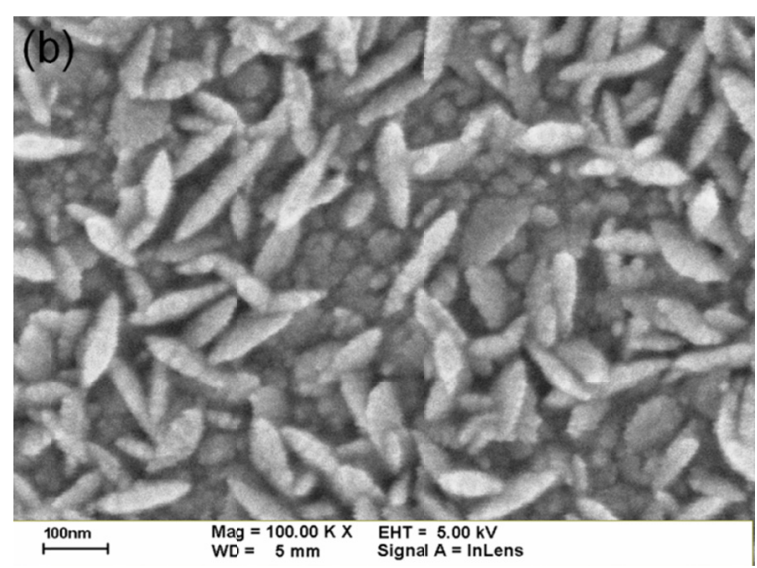

Fig. 3. XPS profile and SEM image of the Pt-Ir electrode after electroplating (a) XPS profile of the Pt-Ir electrode and the atomic ratio of Pt to Ir is Pt (81.3\%)-Ir (18.7\%) (b) the surface morphology of the Pt-Ir electrode which is coved' with disorderd rounded and leaf-like grains.

To examine the properties of the Pt-Ir electrode, Fig. 4 shows that there are two peak currents in the linear sweep voltammetry (LSV) related to the glucose oxidation due to adsorption of hydrogen atoms (left peak) and adsorption of glucono lactone (right peak). In the voltage window betweren $-0.2 \mathrm{~V}$ and $0.2 \mathrm{~V}$, the current response is linear to glucose concentration. Therefore, LSV was used to measure the dynamic changes of glucose concentration. Periodic ramp voltage from -0.6 $\mathrm{V}$ to $0.4 \mathrm{~V}$ and the scan rate of $50 \mathrm{mV} / \mathrm{s}$ was applied on the Pt-Ir sensor. After every 5 cycles, the glucose concentration was subsequently changed from $16 \mathrm{mM}$ through $12 \mathrm{mM}, 9 \mathrm{mM}$, $4.5 \mathrm{mM}$, and $2.25 \mathrm{mM}$ to $1.125 \mathrm{mM}$. Fig. 5 depicts that the electrodes have linear responses to glucose concentrations between 1 to $16 \mathrm{mM}$ with the sensitivity of $0.82 \mathrm{~mA} / \mathrm{mM}$ $\mathrm{dm}^{2}\left(\mathrm{R}^{2}: 0.95\right)$. If the linear range is narrow down to $1 \mathrm{mM}$ to $12 \mathrm{mM}$, the sensitivity would increase to $0.97 \mathrm{~mA} / \mathrm{mM} \mathrm{dm}{ }^{2}\left(R^{2}: 0.988\right)$.

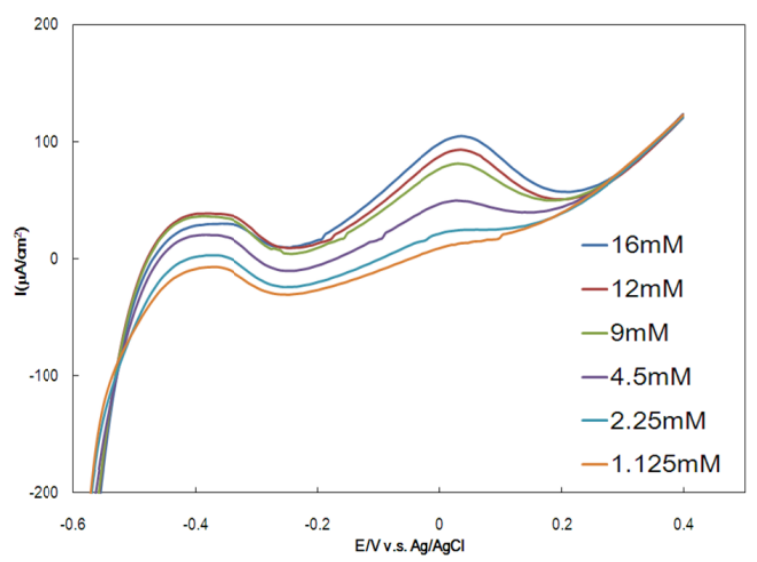

Fig. 4. The linear sweep voltammetry (LSV) of the Pt-Ir electrode in different glucose concentration. Two peaks currents are related to glucose oxidation. 


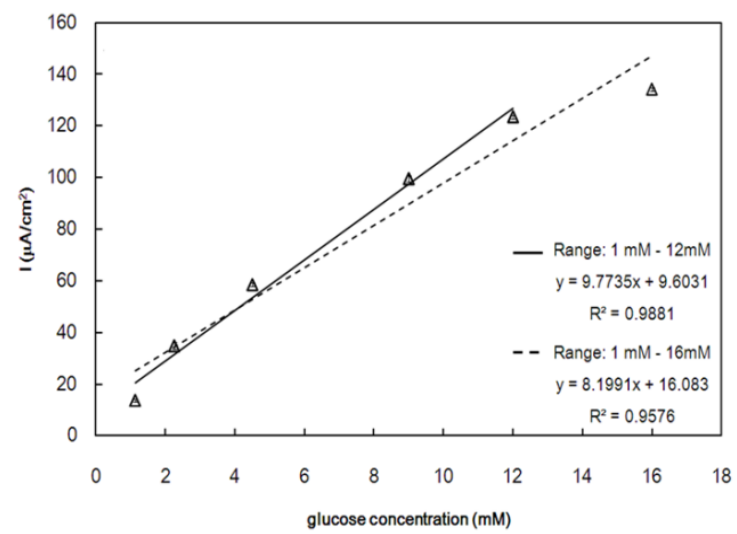

Fig. 5. The calibration curve of Pt-Ir glucose sensor. The sensitivities are $0.82 \mathrm{~mA} / \mathrm{mM} \mathrm{dm^{2 }}$ and 0.97 $\mathrm{mA} / \mathrm{mM} \mathrm{dm^{2 }}$ in the range of $1 \mathrm{mM}-16 \mathrm{mM}$ and $1 \mathrm{mM}$ $12 \mathrm{mM}$, respectively.

\section{Conclusion}

In summary, two electrochemical sensors, IrOx and Pt-Ir sensors, are presented and used for $\mathrm{pH}$ and glucose sensing. These two sensors show stability at $37{ }^{\circ} \mathrm{C}$ for a long period and high sensitivity under high $\mathrm{Cl}^{-}$environment (1X PBS, $0.15 \mathrm{M} \mathrm{NaCl}$ ). Also, the linear range of these two sensors covers the normal range of $\mathrm{pH}$ and glucose concentration used for cell culture. Owing to these characteristics, the presented $\mathrm{IrO}_{\mathrm{x}}$ and $\mathrm{Pt}$-Ir sensors have great potential for use in continuous cell culture monitoring.

\section{Acknowledgements}

The work was supported by Corning Research Center, Taiwan, and NSC 100-2321B-002-079.

\section{References}

[1] A.J. Becker, E.A. McCulloch, J.E.Till, Cytological demonstration of the clonal nature of spleen colonies derived from transplanted mouse marrow cells, Nature 197, 452-454 (1963); doi:10.1038/197452a0

[2] L. Siminovitch, E.A. McCulloch, J.E.Till, The distribution of colony-forming cells among spleen colonies, Journal of Cellular and Comparative Physiology 62, 327-336 (1963); doi:10.1002/jcp.1030620313

[3] L.H. Lee, R. Peerania, M. Ungrin, C. Joshi, E. Kumacheva, P.W. Zandstra, Micropatterning of human embryonic stem cells dissects the mesoderm and endoderm lineages, Stem Cell Research, 2, 155-162 (2009); doi:10.1016/j.scr.2008.11.004

[4] G. Kania, P. Blyszczuk, A.M. Wobus, The generation of insulin-producing cells from embryonic stem cells - a discussion of controversial findings, International Journal of
Developmental Biolog 48,1061-1064 (2004), doi: $10.1387 / \mathrm{ijdb} .041925 \mathrm{gk}$

[5] J. Fukuda, A. Khademhosseini, Y. Yeo, X. Yang, J. Yeh, G. Eng, J. Blumling, C.-F. Wang, D.S.

Kohane, R. Langer, Micromolding of photocrosslinkable chitosan hydrogel for spheroid microarray and co-cultures, Biomaterials 27 , 5259-5267 (2006); doi:10.1016/j.biomaterials.2006.05.044

[6] S.A. Ruiz, C.S. Chen, Emergence of patterned stem cell differentiation within multicellular structures, Stem Cells 26, 2921-2927 (2008); doi: 10.1634/stemcells.2008-0432

[7] V. Vojinovi'c, J.M.S. Cabral, L.P. Fonseca, Realtime bioprocess monitoring Part I: In situ sensors, Sensors and Actuators B 114, 1083-1091 (2006); doi :10.1016/j.snb.2005.07.059

[8] G.J. Mohr, O.S. Wolfbeis, Optical sensors for a wide $\mathrm{pH}$ range based on azo dyes immobilized on a novel support, Analytica Chimica Acta 292, 41-48 (1994); doi: 10.1016/0003-2670(94)000964

[9] B.H. Weigl, A. Holobar, W. Trettnak, I. Klimant, H. Kraus, P. O'Leary, O.S. Wolfbeis, Optical triple sensor for measuring $\mathrm{pH}$, oxygen, and carbon dioxide, Journal of Biotechnology 32, 127-138 (1994); doi:10.1016/0168-1656(94)90175-9

[10] R.J. Gillies, J.-P. Galons, K.A. McGovern, P.G. Scherer, Y.-H. Lien, C. Job, R. Ratcliff, F. Chapa, S. Cerdan, B.E. Dale, Design and application of NMR-compatible bioreactor circuits for extended perfusion of high-density mammalian cell cultures, NMR in Biomedicine 6, 95-104 (1993); doi:10.1002/nbm.1940060115

[11] S.N.O. Williams, R.M. Callies, K.M. Brindle, Mapping of oxygen tension and cell distribution in a hollow-fiber bioreactor using magnetic resonance imaging, Biotechnology and Bioengineering 56, 56-61 (1997); doi: $10.1002 /(\mathrm{SICl}) 1097-$ 0290(19971005)56:1<56::AID-BIT6>3.0.CO;2-U

[12] S.A.M. Marzouk, S. Ufer, R.P. Buck, Electrodeposited iridium oxide $\mathrm{pH}$ electrode for measurement of extracellular myocardial acidosis during acute ischemia, Analytical Chemistry 70 , 5054-5061 (1998); doi:10.1021/ac980608e

[13] I.A. Ges, B.L. Ivanov, D.K. Schaffer, E.A. Lima, A.A. Werdich, F. Baudenbacher, Thin-film IrOx $\mathrm{pH}$ microelectrode for microfluidic-based microsystems, Biosensors and Bioelectronics 21, 248-256 (2005); doi: 10.1016/j.bios.2004.09.021

[14] A.N. Bezbaruah, T.C. Zhang, Fabrication of anodically electrodeposited iridium oxide film $\mathrm{pH}$ microelectrodes for microenvironmental studies, Analytical Chemistry 74, 5726-5733 (2002); doi: 10.1021/ac020326l 